\title{
Baudelaire, Poeta Ejemplar
}

\author{
POR ANDRÉ COYNÉ
}

Resulta siempre algo paradójico celebrar fechas recordatorias de aquellos grandes "centinelas" de humanidad que en vida no encontraron más que desdén, crueldad, o en el mejor de los casos, la curiosidad compasiva, medio burlona de sus contemporáneos, salvo escasas excepciones.

Nos halaga creer a posteriori que de haber sido nosotros los contemporáneos no hubiésemos dejado de advertir el genio misterioso, la gloria oculta, inadvertida; fácilmente también disimulamos los errores que cometemos al enjuiciar a los nuestros, los de ahora, exaltando a quienes ya murieron, los de anteayer mejor aún que de ayer. Muchas veces la exaltación no es sino exaltación de la vanidado propia, comolesos lelogios de cementerio que sacan pretexto del muerto para poner en relieve la elocuencia del sobreviviente.

No quiero hacer hoy día el elogio de un muerto, no quiero del poeta condenado de 1857: no nos hemos juntado para cubrir de flores de retórica, luego marchitas, al autor de las Flores, siemprevivas, del árbol del mal, árbol de ciencia, de pasión y de poesía. Por lo demás ¿quién entre los que estamos aquí sin excluir a aquellos que muy alto proclaman su admiración hacia el poeta -quien podría asegurar que, de aparecer de pronto Baudelaire en carne y hueso, dotado oún de vida física, inmediata, lo reconocería y lo recibiría con palabras o una actitud espiritual que él aceptara y a su vez reconociera? En realidad, un siglo de ventaja sobre los contemporáneos no nos permite afirmar que Baudelaire encuentre entre nosotros mucha mayor comprensión -analogía del alma y de los sentidos. 
Existe una justicia histórica que recoge las grandes obras solitarias del pasado y paulatinamente las incluye en un fondo común que todos heredamos; pero la justicia del tiempo es insidiosa: a todos ofrece por igual su caudal de riquezas acumuladas, no enseña la forma de gastarlas, menos aún de extraer de ellas el fruto que pueden madurar. Concretándonos a obras literarias, ¿cómo no recordar aquí las advertencias de Proust sobre la lectura, que, si bien nos introduce ocasionalmente a la vida espiritual, de ninguna manera la substituye, tampoco la constituye?

Nadie un poco leído aceptaría en 1957 censurar a Baudelaire con las razones del siglo XIX; nadie caería todavía en el ridículo de negar la trascendencia de su nombre. ¿Vale decir que hemos adelantado desde entonces en nuestros juicios y prejuicios? Desde luego que no; ha pasado tiempo, eso es todo. Baudealire ha ido integrando, junto con otros "malditos", el patrimonio humano al cual acabo de referirme; comentamos su obra en las escuelas, lo admitimos en las bibliotecas, y no dudamos de nuestra superioridad sobre los parisinos de hace cien años que no supieron distinguir la grandeza del hombre y del poeta. Pero, el mundo más que nunca está hecho "de gente que no piensa sino en común, en cuadrilla"; el número de quienes rechazan toda aventura espiritual y creer que basta leer de ligero cualquier obra maestra para comulgar en ella) no ha disminuído, no puede disminuir; silos filisteos de hoy se precian de estimar a Baudelaire, no es que tenganirira sensibilidad que la de sus abuelos, sino que han nacido unos cuantos decenios más tarde, cuando ya no era posible ignorar lo que todos los manuales de literatura, muchos escritos también por filisteos con pelo de ilustrados, repiten en todos los idiomas.

Cuando, por el año de 1866, un grupo de poetas principiantes entre ellos Verlaine, quiso proclamar a Baudelaire jefe de la nueva escuela poética, en carta a un amigo, éste confesó el miedo que le inspiraban tales jóvenes, algunos con talento, pero exagerados, y sobre todo de mente confusa, incierta: "Nada me gusta tanto como estar solo".

Ya célebre y Baudelaire muerto tiempo atrás, José María de Heredia recordaría igualmente su "presentación" al poeta de Las Flores del Mal: "Me consideró con frialdad, clavando en mí sus ojos agudos como dos granos de café negro, y cortando mis fórmulas de admiración respetuosa, me dijo: "Caballero, no me interesan los jóvenes". Luego calló, dándome la espalda". 
La soledad de Baudelaire no lo ha preservado del aplauso consiguiente de los entendidos y de los necios; no lo preserva hoy de nuestro homenaje; al menos convendría despojar este acto de todo carácter impersonal, hasta diría de todo carácter colectivo, para cada uno de nosotros tratar de merecer por cuenta propia acercarse a alguien que nunca alcanzaremos, pero que tal vez podemos acechar desde el rincón del alma, olvidados de nuestros intereses, de nuestras vanidades, en primer lugar de la vanidad de la inteligencia; y si es necesario que alguien hable en voz alta, ya que la etiqueta social lo exige, guardemos un silencio más profundo para oír la voz que íntimamente nos diga la dificultad, el pavor de ser hombres, y al mismo tiempo nos hable el dúctil lenguaje cuyos acentos nos resultan extraños sólo porque desconocemos casi todos el secreto de la vida.

Reunidos en un homenaje a Baudelaire, procuremos abstraernos de quienes nos rodean, cada cual solitarios en medio de otros solitarios, en espera de la única comunión posible: comunión de soledad, con aquel que escribiera en Mi corazón al desnudo: "Desde niño, conciencia de la soledad. A pesar de la familia y sobre todo entre mis compañeros - conciencia de un destino eternamente solitario. Sin embargo, viva inclinación por la vida y el placer".

Volveremos sobre el último punto; por ahora, bástenos colocar nuestra reunión de hoy bajo el signo inequívoco de la soledad, soledad del geniog queur noinos latañevverdaderamente sino cuando admtimos que nos revela, en forma absoluta y ejemplar, la soledad de toda alma humana, por más que, ebrios de ruido y de luces, no tengamos generalmente el valor de permitirla. Nadie recibirá la revelación auténtica de la poesía, que no se despoje primero de cuanta hojarasca lo separa de sí mismo: engaños del decoro, de la decencia, de la adulación o del discurso.

En Abril de 1864, Baudelaire fué a Bruselas para dictar una serie de conferencias sobre Delacroix, Gautier y los "paraísos artificiales"; algún público acudió a la primera, pero uno de los asistentes recuerda que, ya en la segunda, Baudelaire habló delante de veinte personas: "Les habló como si hubiese hablado ante una corte de príncipes, revelándoles a un Gautier altísimo, igual de los grandes Papas del arte... Desenvolvía sus períodos con una unción casi evangélica; promulgaba sus dilecciones por un maestro venerado con la voz litúrgica de un obispo que enunciara instrucciones. Indubitablemente celebraba para sí mismo 
una misa de gloriosas metáforas; era hermoso y grave como un cardenal que oficiara ante el Ideal... Al cabo de una hora el poco público enrareció aún más; alrededor del mágico del Verbo, el vacío logró vaciarse más: no quedaron sino dos banquetas.

Como primera imagen concreta de Baudelaire ¿cómo no evocar ese vacío en torno al intérprete magnífico, físicamente magnífico de los arcanos de la creación y de la suerte? ¿Qué soledad más evidente, ridícula y aterradora, que la del conferenciante que habla para los bancos y las paredes? simultáneamente, tratándose de Baudelaire jqué pronto el ridículo se cierne no sobre el orador, sacerdote de un culto que no deja de obrar por ausencia de fieles, sino sobre los ausentes, dedicados a Dios sabe qué, sin sospechar la oportunidad que están perdeindol Y para nosotros qqué lección de modestia, en primer lugar para quien hablal no he hecho la cuenta de cuántos estamos, pero me parece que más de veinte, atraídos por la buena reputación de Baúdelaire; no olvidemos, mientras quedamos juntos, esa otra sala de conferencias, de Bruselas, donde, con corbata blanca, en medio del estrado, el poeta se inclinaba, después de un último saludo a la poesía, ante una asistencia disminuída, casi evaporada.

El habia hablado, aquel día, de Théophile Gautier, y si juzgamos por un arfículolanterior dedicados al autor de La Comedia de la Muerte, podemos imaginar que había denunciado una vez más "la Industria y el Progreso, despóticos enemigos de toda poesía" y comparado al poeta con "un diamante siempre más raro en una época embriagada de ignorancia y de materia". Lo primero que Baudelaire nos descubre de la poesía es su extrañeza radical en el mundo tal como somos obligados de vivirlo, su extrañeza y su inutilidad, garantes de una adecuación más profunda con nuestro espíritu y de una postrera, inexplicable reconciliación del hombre con las cosas.

"La vida de Poe, sus costumbres, sus modales, su ser físico, todo lo que constituye el conjunto de su personaje, nos aparecen como algo tenebroso y a la vez brillante. Su persona era singular, seductora y, como sus obras, marcada de un sello indefinible de melancolía". Lo que dice de Edgard Poe, el traductor de las Historias Extraordinarias, lo dice anticipadamente de sí mismo, lo dice de todos aquellos (todos, pero no muchos) que me- 
recen figurar las estrellas del cielo nocturno, oscuro y radiante, de la poesía.

Las páginas sobre Poe son reveladoras: "Repito que para mí Edgard Poe y su patria no estaban de nivel"; pero ¿qué poeta está de nivel con su patria? y cuando Baudelaire escribe: "Hay en la historia literaria... unos hombres que llevan las palabras mala suerte estampadas con caracteres misteriosos en las arrugas sinuosas de su frente... En vano su vida ostenta talentos, virtudes, gracia; la sociedad les reserva un anatema especial y acusa en ellos las deficiencias de las que ella misma se hace responsable al perseguirlos..."; cuando pregunta: "¿Existen pues almas sagradas, prometidas al altar, y condenados a andar hacia la muerte y la gloria a través de sus propias ruinas?..."; . cuando adhiere a la tesis de Vigny en Stello: "Un escritor famoso de nuestro tiempo ha escrito un libro para demostrar que el poeta no encuentra sitio ni en una sociedad democrática, ni en la aristocrática, ni en una república, ni en una monarquía absoluta o moderada", ¿quién podría contestarle perentoriamente? No cabe duda, que, para él, el destino del poeta es un destino aparte, que no se acomoda de ninguna convención, por lo tanto de ninguna sociedad, al menos de ninguna de las sociedades que conocemos o que estamos llamados en adelante a conocer.

El carácter primitivo de la poesía, lo podemos encontrar en su desconformidad con las modas vigentes, los órdenes vigentes, acá y acullá. Poesía, fuerza disgregadora de mentiras, disgregadora de ilusiones. Quedan por cierto descalificados de antemano tantos poetas, o llamados poetas que prefieren sacar provecho de la poesía, prostituyéndola al servicio de esto o de aquello, o, con menos peligro aún, confundiéndola con la alabanza propia y de. los camaradas, poetas de corrillo, poetas adocenados, poetas por oficio y por acomodo, que llenan las hojas públicas y los tablados, histriones del arte que, ellos sí, reciben acogida (¿cómo no la iban a recibir?) de una sociedad a la que dan buena conciencia de sí misma: sus diabluras no pasan de límites admitidos y sus impertinencias, hasta sus gritos sediciosos son celebrados como gracias de la función que desempeñan.

Tal vez sea este el único "progreso" desde Baudelaire: que los poderes materiales que él reprobara como despóticos enemigos de toda poesía", dándosela a veces de cultos, simulen favorecer a los poetas, aun cuando estos los desprecian; sólo importa que no desprecien su dinero, y comprometen a la poesía, co- 
mo una actividad como cualquier otra, que redunda en un bien general, es decir el beneficio de unos cuantos. Progreso de la hiprocresía y de las conveniencias recíprocas. Mientras tanto, los auténticos predestinados siguen viviendo y muriendo "extraordinariamente solitarios", aun cuando la "sociedad" trata de recuperarlos después de muertos y honrar su memoria para mejor traicionarla.

Baudelaire no tenía todavía 25 años cuando intentó suicidarse con un cuchillo; perdió el conocimiento y él mismo contaba después a Louis Ménard que había despertado en una comisaría, oyendo el runruneo del comisario que le decía: "Joven, Ud. acaba de cometer una mala acción... A su edad uno se debe a su familia, a su barrio, a su calle..." y corto de razones, el buen hombre habría agregado "uno se debe a su comisario...". Hallazgo admirable en boca del representante de la sociedad, que no entiende que uno pueda desconfiar de la vida hasta olvidarse de todo "deber" y arrogarse el "derecho" de suprimirla en carne propia. Es posible que Baudelaire se haya acordado del episodio, años más tarde, cuando en el estudio sobre Poe, escribiría: "En la enumeración de los derechos del hombre que la sabiduría del siglo XIX vuelve a enumerar a cada instante, satisfecha y complacida, dos bastante importantes han sido totalmente olvidados: el derecho de contradecirse y el derecho de irse", el derecho de separarse, desligarse:tla sociedad no admite ser juzgada en forma tan absoluta, donde no cabe la posibilidad de "recuperar" al rebelde.

La víspera de su acto frustrado, Baudelaire había discutido con Ménard la mejor manera de "suprimirse" y, entre burlas y veras, el hijo de Mme. Aupick había declarado a su compañero, quien creía seguir una broma: "Los periódicos de gran formato me vuelven la vida insoportable, he resuelto matarme" - queja acerca de los diarios de gran tirada que acababan entonces de aparecer, jcuántos medios nuevos de información, en realidad de propaganda, de nivelación, hemos inventado desde la fechal y jcon cuantos más motivos podría Baudelaire quejarse hoy en día de la "despiadada dictadura de la opinión"l

En Junio de 1845, fecha de la tentativa de suicidio, el joven escritor ya tenía escritos varios de los poemas reunidos en Las 
Flores del Mal y en los diez años sucesivos iba a componer la casi totalidad de su obra poética, a lo más ciento cincuenta poemas, uno solo un poco largo. La poesía vendría a constituir la actividad redentora que salva lo único que puede ser salvado de la vida: imágenes libradas del abismo como para dar testimonio de "otra cosa" a que estaríamos secretamente adaptados. Baudelaire: no quiero decir el más grande para no levantar polémicas inútiles, pero sí el más lúcido de los poetas, el más consciente del objeto de toda poesía y de la suerte reservada a quien lo observa heroicamente, con la percepción continua del abismo, "abismo de la acción, del sueño, del recuerdo, del deseo, del pesar, del remordimiento, de la belleza, del número, etc...".

25 de Junio de 1857: el editor Poulet-Malassis pone en venta un libro de poemas, no muy extenso, que hubiera podido llamarse Las Lesbianas o Los Limbos y finalmente ostenta el título ambiguo de Las Flores del Mal. No han pasado diez días, cuando un artículo de El Fígaro denuncia las "monstruosidades" de los versos, inadmisibles bajo la pluma de "un hombre de más de treinta años" (sic), y los señala a la aiención de la justicia, que el 16 de julio, se incauta de la edición y abre una demanda contra el autor y su editor. Finalmente el 20 de Agosto, el tribunal correccional condena a Baudelaire y a Poulet-Malassis al pago de una multa, y decreta la supresión de seis poemas de Las Flores del Mal.

El juicio y el escóndalo consiguiente han profundamente herido al poeta, quien más que nunca lamentará en, sus cartas "el contraste ofensivo, hasta repugnante, entre su honradez espiritual y su vida precaria y miserable"; no han podido sorprenderlo tanto como ciertas veces lo insinúa. El nunca había puesto en duda, ya lo dijimos, cuan desconforme estaba con el medio en que le tocaba vivir y (lo mismo que más tarde aspiraría a la Academia ya la Legión de Honor sólo para probar a aquellos que no entienden otras razones la "dignidad" profunda de su vida, pero sin creer mucho en el éxito y sobre todo sin rebajarse a ninguno de los compromisos que el éxito hubiese exigido), los proyectos de Prefacio que un tiempo prepara con miras a una segunda edición de su libro, "expurgado" y enriquecido con poemas inéditos -la edición de 1816-, amén de quedar todos inconclusos, nos demuestran, si fuera necesario, la conciencia aguda que el poeta tiene de su diferencia, en una época ilustrada (no en vano el mundo moderno empieza con la "Ilustración" y el siglo XIX 
se proclama heredero del "siglo de las luces"), en una época ilustrada, más insensible a cuanto no descubre utilidad o se aparta de los cánones morales aprobados por el sufragio universal y las "hojas públicas".

Para disuadir a sus detractores, Baudelaire, en las notas a que aludo, se limita a invocar la necesidad suya de hallar una provincia poética no explorada cuando los poetas ilustres ya tenían repartidas entre sí "las provincias más floridas del reino": "Este libro, esencialmente inútil y absolutamente inocente, no ha sido escrito sino con el fin de divertirme y ejercitar mi pasión por el obstáculo" - declaración de inocencia, confundida con la inutilidad, ante un mundo que lo acusa y lo juzga, torpe disculpa si se tratara verdaderamente de encontrar disculpas, pretexto del arte gratuito, del "bello estilo", que el escritor aduce tan sólo para subrayar la distinción de lo Bueno y de lo Bello, y de nada le serviría, o nueyas críticas merecería, si alguien lo tomara en cuenta. En realidad, más que disculpa tenemos un desafío a cualquier clase de crítica: el artista finge humillarse, limitar el alcance de su obra, al calificarla de graciosa y decorativa, pero, de llegar el texto a publicarse, la aparente sumisión, había de resolverse a renglón seguido en el grito condenatorio del acusado que de pronto se trueca en acusador frente a sus jueces y denuncia la fe en el "progreso" parā concluir: "Nuestro mundo ha llegado a tal espesor de vulgaridad que el desprecio por el hombre espiritual ha gaquirido la violenciar de "una pasión".

En otro proyecto sensiblemente posterior, para una tercera edición de Las Flores del Mal que no llegó a realizarse, vemos a Baudelaire abandonar hasta la apariencia de la justificación y expresar únicamente su desdén de todas las censuras y el cansancio que lo invade sólo al pensar que podrían exigir que se explicara: "No tengo ningún deseo de demostrar, ni de sorprender, entretener o persuadir... Aspiro al descanso absoluto y a la noche continua... No saber nada, no enseñar nada, no querer, no sentir nada, dormir, siempre dormir, tal es hoy día mi única ilușión...". Cansancio de argüir entre pedantes, cansancio de vivir una vida frustrada que la hostilidad del ambiente sanciona si no la motiva cabalmente: más perjudicial aun que la hostilidad marcada de la justicia cuando el proceso de 1857, la hostilidad solapada, hipócrita y muda que manifiesta el trato cotidiano con la estulticia, la fealdad y la miseria. 
El cansancio posterga y paulatinamente destierra toda actividad creadora; pero ésta en ningún momento ha incurrido en el simple ejercicio o la persecución exclusiva de la forma. Nadie más alejado que Baudelaire de los cultores del "arte por el arte", con los cuales un tiempo se lo ha confundido, cuando abría el camino a quienes consideran la poesía "no sólo como un producto escrito, una serie de imágenes y sonidos, sino como una manera de vivir" (Tzara).

Si en el primer proyecto citado, el autor alegaba que Las Flores del Mal eran producto de la voluntad de "divertirse", nos basta abrir el libro para comprobar que esa "diversión" lo compromete, y nosotros inmediatamente con él: el volumen, que reunía poemas desde 1824, era obra más bien "de furor y paciencia" (Carta de Baudelaire a su madre, 9 de Julio de 1857), obra en la cual nada, hasta el orden minucioso de los poemas, quedaba indiferente, sujeto al capricho 0 al asombro. En carta a Ancelles de 1866, un año antes de morir, Baudelaire confesaría retrospectivamente: "¿Es necesario repetirle... que en ese libro atroz he puesto todo mi corazón, toda mi ternura, toda mi religión (disfrazada), todo mi odio?" y agregaría, motivando algunas de sus denegaciones intermedias: "Es verdad que seguiré escribiendo lo contrario, jurando por lo más sagrado que es un libro de arte puro, de parodia, de malabarismo, y mentiré como un sacamuelas". En varias ocasiones jel poeta se había teferido a la importancia de juzgar su libro, no por trozos separados, sino en conjunto: "y entonces "resalta una ferrible moralidad".

La palabra misma "moralidad" puede parecer equívoca y desmentir tantas otras páginas en que Baudelaire afirma rotundamente, contra toda clase de poesía "didáctica", la amoralidad del arte que "propende a un fin distinto al de la moral", satisfecho "con la belleza de la concepción y del estilo". Pero lo condenado es "la enseñanza moral", no el "significado moral", oculto en la obra y que los lectores enterados "adivinan": en parte porque la belleza de por sí encierra o debería encerrar una moralidad más alta; sobre todo, por ser la poesía el lugar privilegiado para la aventura espiritual del poeta.

Por moral ahora no entendemos un código de leyes y de prohibiciones, sino, mediante el ritmo y la metáfora, el confron- 
tarse de un hombre con el destino, bajo la luz impostergable de la conciencia. "Baudelaire, escribe Sartre, en el ensayo que le ha dedicado, es ei hombre que nunca se olvida de sí mismo": "su actitud original, primera, es la de un hombre inclinado inclinado hacia sí mismo, como Narciso"; pero el milagro estalla cuando semejante actitud culmina en la escritura, y el hombre se esfuma tras el poeta.

Partiendo de las indicaciones que acabo de mencionar, relativas a la "moralidad" de los poemas si se les considera todos juntos, Marcel Ruff, en una tesis reciente, El espiritu del mal y la estética baudelertana, se ha propuesto rastrear en la ordenación de los versos, en 1857 como en 1861, el tema del poeta y sus variaciones: tema del mal (había que fijarse en el título), de acuerdo con la condición terrestre del poeta, "en la perspectiva de la reversibilidad de los méritos, "y también a la justicia y la misericordia divina". En todo aquello encuentra el crítico la novedad máxima del libro de Boudelaire, sin dejar de reconocer que él indica una "arquitectura a posteriori", y no conisdera el impacto poético propio de cada poema, escrito en una fecha variable, fuera de todo propósito demostrativo, ni, por consiguiente, apologético.

El análisis de Ruff es interesante $y$, desde que aceptamos sus primicias, generalmente convincente. Pero viene un siglo después de la obra (loique öexplicaría" que lose contemporáneos se hayan "equivocado" al leerla), sin traernos en definitiva nada substancialmente nuevo acerca del secreto de Baudelaire y de la fascinación que sus versos siempre ejercerán, sin necesidad de explicaciones dogmáticas.

Bastante conocíamos ya el cristianismo, el catolicismo de Baudelaire, con una filosofía que procede de Joseph de Maiestre, "defensor acérrimo, para atenernos a una fórmula del Larousse, defensor acérrimo del principio de la autoridad en materia política y religiosa". Catolicismo de Baudelaire que explica por ejemplo que, después de reivindicarlo en el Primer Maniffesto de 1924 ("Baudelaire es surrealista en la moral") y antes de volver a una apreciación más serena, en el Segundo Manifiesto del SuBaudelaire y la regla eterna de su vida: rezarles cada mañana a Dios, reserva de toda fuerza y justicia, a mi padre, a Mariette y a Poe, como intercesores". Por otra parte, no obstante la persistencia del vocabulario católico, la posición moral de Baudelaire. no deja de ser, digamos, "sospechosa", para que un ortodoxo es- 
tricto como Claudel se haya creído autorizado a juzgar al poeta con una de esas sentencias despectivas con que reprobaba toda la centuria pasada: "El ha cantado la única pasión que el siglo XIX podía aún experimentar: el remordimiento".

Opiniones la una como la otra de quienes no aceptan a Baudelaire globalmente, con las contradicciones, sin embargo ejemplares, de su obra y de su vida. Para nosotros, en la encrucijada de la tradición y de lo que él mismo llamara la vida moderna, Baudelaire es probablemente el único artista en asumir la totalidad de la experiencia humana, por lo que cabe en ella de triunfo como de fracaso. Su admirable lucidez, si es cierto que le impidió entregarse a todas las solicitaciones de la aventura, también lo preservó de la tentación de "angelismo", frecuente en los discípulos, y su rebeldía, si a primera vista no nos lleva tan lejos como la de Rimbaud o de Lautrémont, luego nos atañe más profundamente en cuanto es rebeldía de adulto, partícipe del mal y consciente de los límites de su naturaleza.

Tenemos al hombre desgarrado por "dos postulaciones simultáneas, una hacia Dios, otra hacia Satanás", el hombre que "a la una de la madrugada", cuando la gente duerme o se divierte, se examina y "recapitula el día", descontento de (sí mismo), tratando de "redimirse y enorgullecerse un poco en el silencio y la soledad de la noche" con la esperanza de unos hermosos versos". El hombre despiadado con su propia debilidad y que sólo por ello puede también imprecar a todosclos falsos idolos sde su alrededor, herejes en la moral (la moral auténtica) como en el arte: Musset, "femenino y sin doctrina", "sepulturero lánguido", "maestro de pisaverdes" y de todos aquellos que "ignoran que el genio (si así llamamos al germen indefinible de los "grandes hombres) debe, igual que el aprendiz de saltimbanqui, arriesgar mil veces romperse los huesos en secreto antes de bailar frente al público; en una palabra que la inspiración no es sino la recompensa del esfuerzo cotidiano" - Víctor Hugo, "romántico y pensador", que se imagina ser un nuevo Prometeo, aplicándose en el pecho un buitre imaginario, y canta todas "las estupideces propias del si. glo XIX" - Jorge Sand, a quien "el Diablo ha persuadido que confiara en su buen corazón y su buen sentido, para que a su vez convenciera a los demás animales de creer también en su buen corazón y su buen sentido", etc. - basta de citas que podríamos multiplicar, conforme Baudelaire va sufriendo más y más de 
los "prejuicios contemporáneos": "ideas falsas" y "modas del pensamiento".

Pero (ya lo comprobaba nuestra cita del poema en prosa A la una de la Madrugada), la redención, al menos en vida, Baudelaire la plantea, no en términos religiosos, sino en términos poéticos, y es entonces cuando su ejemplo seduce a muchos que no comparten su "filosofía", al mismo tiempo que aleja a los "creyentes" contentos con su fé. La moral de la poesía es una moral de la creación, no una moral de los actos, buenos o malos. "Ser siempre poeta, aun en prosa" (1): cuando Baudelaire proclama el culto de las imágenes ("mi grande, mi única, mi primitiva pasión"), y califica a la imaginación de "super naturalista" (la imaginación, "reina de las facultades", hasta en la moral, pues "¿qué es la virtud sin imaginación?"), cuando insiste en la analogía universal y apoya su poética en las correspondencias, los bosques de símbolos que le toca al poeta descifrar, asienta las bases de la poesía moderna, libre de las trabas del sentimiento y del discurso y devuelta a su función primigenia, mágica, casi impersonal, en el tiempo y fuera del tiempo: la poesía que nos descubre, pordètrás de las aparienciás, la realidad del universo.

"Horror de la vida, éxtasis de la vida": nadie como Baudelaire ha experimentadb Cel primero, ny pocos poetas hasta él habían propuesto, como fin exclusivo de la poesía, sugerir, mejor que sugerir: imponer con palabras el segundo. Extasis, es decir arrobamiento, es decir goce. Perspectivas propiamente religiosas, pues si el poeta define a la poesía como lo más real que existe (2) y "totalmente verdadero sólo en otro mundo", no habla forzosamente del otro mundo, sino de otro mundo en el mundo, alcanzado en el más acá: mundo efímero y eterno, apariencia y esencia. La inqiuetud religiosa puede aquejar el alma de Baudelaire; su experiencia poética resuelve la inquietud según normas propias que la religión. no admitiría; y tal vez sea por esta concepción de la poesía, mejor que por las interpretaciones mo-. rales, como tengamos que explicar el juicio severo de Claudel,

(1) Novalis decia: "Estar siempre en estado de poesía".

(2) Novalis: "La poesia es lo verdadero, lo absolutamente real". 
tanto como cierta fidelidad de Breton a Baudelaire a pesar de tantas discrepancias.

Poesía: goce... "En ciertos estados del alma, escribe Baudelaire, en ciertos estados del alma casi sobrenaturales, la hondura de la vida se nos revela, entera, en el espectáculo, por más ordinario que sea, que tenemos a la vista, y se vuelve símbolo de ella". Habría que subrayar el adverbio casi, el cual implica una espiritualidad al margen, un misticismo de carácter naturalista o supernaturalista, no exactamente sobrenatural $i$ pero sabemos que el acierto de la poesía queda ligado a esa traducción - itraducción? no- comunicación de una "vida suprema", conocida "ahora" mismo y gozada; de nada importa que el goce a veces sea provocado por un excitante; puede nacer en cualquier momento, de manera imprevista, tal una "gracia" que transforma la existencia ordinaria: "El tiempo ha desaparecido; reina la eternidad, una eternidad de delicias".

Delicias del espíritu y delicias de los sentidos: las unas y las otras están unidas, confundidas. Hay poetas, como Novalis, cuya sensualidad parece depurada de todo contacto inmediato: "Actio in distantia... Todo, en la distancia, se torna poesía o poema...". Pero nadie es poeta sin los cinco sentidos: Baudelaire proclama la equivalencia de clertos perfumes, colores y sonidos; apenas necesito recordar la importancia en su obra poética, al lado de las sensáciones tradicionales de la vista $o$ del oído, de las sensaciones olfativas:

\section{"Jorge Puccinelli Converso»}

"... ¡ perfume cargado de indolencial ¡Extasis!...".

El éxtasis a menudo nace cuando el poeta respira el perfume de una mujer. En carta a Sainte-Beuve, Baudelaire se define como "un hombre que tanto ha gustado del perfume de la mujer", y una nota del Diario relaciona la definición con los primeros recuerdos de niñez: "Yo confundía el olor de las pieles con el olor de la mujer...". Harto conocida igualmente es la página de Los Paraísos Artificiales que explica la delicadeza, la sutileza de "los genios superiores" en el universo artístico, porque han "bañado, desde el comienzo y por mucho tiempo, en la blanda atmósfera de la mujer, el olor de sus manos, de su seno, de sus rodillas, de su cabellera, de sus vestidos suaves y ondeantes". 
No olvidemos tampoco que el olfato, si bien revela las sensualidades más ávidas de goce, por lo mismo resulta en la perspectiva "supernaturalista" que antes indicamos, el sentido más espiritual de todos: respirar el perfume del cuerpo, es apropiarse su esencia; en el Himno "a la muy amada, a la muy bella, "ángel, ídolo inmortal", se realiza la fusión (algunos dirían en tono de censura: la confusión) de lo sensual y de lo espiritual:

"Ella se esparce en mi vida
Como aire impregnado de sal,
Y en mi alma insatisfecha
Vierte el amor a lo eterno...

Hombre que no renuncia a la tierra para explorar lo que la tierra esconde, el poeta quisiera "adueñarse inmediatamente, y en esta tierra misma, de un paraíso revelado". Poseer la verdad en un alma y un cuerpo", dirá Rimbaud, quien saludará a Baudelaire como al "primero de los Videntes". Tendríamos que emprender ahora el comentario de poemas como la La Cabellera, El Balcón o La Muerte de los Amantes para justificar el entusiasmo del adolescente que iba a escribir Las Iluminaciones, pero la traducción de los versos a otro idioma les quitaría parte de su hechizo, y préfieró referin textualñnente unos párrafos de dos textos en prosa del Esplín de París, que corresponden a sendos poemas de Las Flores del Mal, y dandoldeentender, mejor que todo comentario extraño, el mecanismo, si cabe la palabra, de la "hechicería evocatoria" de Baudelaire.

La primera cita, de Un Hemisferio en una Cabellera: "Déjame respirar largo tlempo, el olor de tus cabellos, y hundir en ellos mi rostro, como hombre sediento en el agua de una fuente, y agitarlos con la mano como pañuelo oloroso, para sacudir recuerdos en el aire.

iSi pudieras conocer todo lo que yo veol jtodo lo que yo respirol jtodo lo que yo oigo en tus cabellosl Mi alma viaja en el perfume como el alma de los otros hombres en la música. les, etc...

Tus cabellos contienen un sueño, lleno de velas y másti-

Déjame morder largo tiempo tus trenzas pesadas y negras. Cuando mordisqueo tus cabellos elásticos y rebeldes me parece que estoy comlendo recuerdos". 
El otro fragmento de la Invitación al Viaje, prosa más explícita que el poema con igual título: "Existe un país magnífico, Jauja lo llaman, sumido en las brumas de nuestro Norte y que podríamos calificar como el Oriente del Occidente, la China de Europa, por lo que la cálida y caprichosa fantasía... paciente y obstinadamente lo ha ilustrado con sus sabias y delicadas vegetaciones...

Existe una comarca que a tí se parece, donde todo es hermoso, rico, tranquilo, honrado... donde se respira suavemente la vida, y la dicha armoniza con el silencio. Ahí debemos ir para vivir, ahí debemos ir para morir..

País singular, superior a cualquier otro, así como el Arte es superior a la Naturaleza, donde ésta resulta reformada por el sueño, corregida, embellecida, refundida...

Flor incomparable, tulipón redimido, alegórica dalia, es ahí ¿no es cierto? a ese país hermoso, tan tranquilo y soñador, donde deberíamos ir a vivir y a florecer? Acaso ¿no estarías inserta en tu analocía, y no podrías mirarte, para hablar como los místicos, en tu propia correspondencia?

Esos tesoros, esos muebles, ese lujo, ese orden, esos perfumes, esas flores milagrosas, eres tú. Y eres tú también, los grandes ríos y los quietos canales. Esos enormes navíos que ellos arrastran, cargados de riquezas, y de los cuales salen los cantos monótonos de la maniobra, son amis pensamientos que duermen y ruedan por tu senor."ge Puccinelli Converso"

No quiero prolongar las citas; ellas nos han mostrado el trabajo de la imagianción que "descompone todo lo creado $\mathrm{y}$, con materiales acumulados y dispuestos según unas reglas cuyo origen se encuentra en-lo más hondo del alma, crea un mundo nuevo, produce la sensación de lo inédito" - la imaginación que en un principio "creó el mundo", y "es justo" por lo tanto "que lo siga rigiendo": la experiencia del poeta se separa de la experiencia religiosa, comprobamos una vez más que su ambición es tan alta.

Que el sueño salga al encuentro de la sensación o que la sensación determine el progreso del sueño, la "gracia" poética surge por obra de la imaginación que, "reina de nuestras facultades", es también "la más científica" de todas, "pues abarca la analogía universal, o lo que una religión mística llama la correspondencia". En los Diarios Intimos, encontramos una nota revela- 
dora que glosa, si fuera necesario, tantos versos en que la imagen del navío abre al alma el camino de sí misma: "Estos bellos y grandes navíos, que se mecen (se contonean) imperceptiblemente en las aguas tranquilas, estos vigorosos navíos, de aspecto-desocupado y nostálgico, ¿no nos dicen en un idioma mudo: ¿Cuándo marchamos para la dicha?".

Poesía: invitación al viaje, invitación a la dicha, en un país siempre soñado, y que podemos situar en diferentes latitudes (Trópicos, Holanda, etc.), pero que no alcanzamos sino en esos momentos esplendentes de transfiguración - transfiguración del mundo- que la poesía prolonga cuando acierta a "hablar al alma en secreto su dulce idioma nativo". Transfiguración intermitente, que tal vez deberíamos encaminar a una verdadera ascética, sin que dejemos de preferir su "voluptuosidad inmediata": "agudeza del pensamiento", entusiasmo junto "de los sentidos y del espíritu.

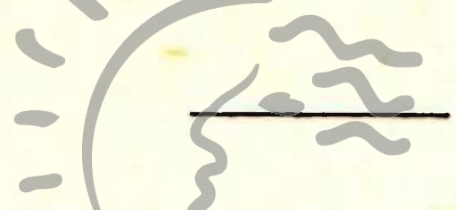

"Ser siempre poeta": los momentos felices de la "alquimia lírica" tienen recaídas cuanto más terribles, más angustiosas; el Tiempo vuelve a aparecer $\mathrm{y}$, con el "horrible anciano", toda la retahila de los Recuerdos, los Espasmos, das Cóleras, los Pavores, las Pesadillas, las, Neurosis - el Tiempo que nuevamente impele al hombre hacial Iaivida insoportable, la Vida implacable, la Vida de esclavo, de réprobo. El poeta es entonces el que no se deja engañar por ninguno de los señuelos de la actualidad, y lleva sobre el mundo una mirada que nada perdona, ni justifica. Cuando no cede al conjuro del poeta-mago, el mundo se descubre pavoroso, trunco, abyecto. A Jules Janin, prototipo del literato satisfecho, Baudelaire preguntaba si lo contentaban los espectáculos de la tierra: "iCómol IA Ud. nunca le ha entrado gana de irse, aunque fuese sólo por cambiar de espectáculol Tengo motivos muy serios para compadecer a quien no ama a la muerte".

En un ambiente hostil, en que el martirio cotidiano de la incomprensión agrava el martirio de ser hombre y como hombre atenazado entre las garras del tiempo, Baudelaire, poeta de la "modernidad" es simultáneamente quien lanza las primeras imprecaciones contra el mundo moderno - recordemos la frase ya 
citada sobre la época "ebria de ignorancia y de materia" ignorancia materialismo no tanto de los analfabetos ( $y a$ que muy pocos quedan) como de los alfabetos, y hasta de muchos profesionales de la inteligencia. En una sociedad que todavía cree en un Progreso indefinido, Baudelaire se adelanta a su tiempo $\mathrm{y}$, penetrando de lleno en el Apocalipsis, escribe: "El mundo va a terminar. La única razón por la cual podría durar, es porque existe. ¡Qué débil me parece esta razón, comparada a todas aquellas que anuncian lo contrario y especialmente a esta: ¿qué puede tener que hacer en adelante el mundo bajo el cielo?" - advertencia profética, cuyos alcances no hemos acabado aún de medir.

Ilusiones del siglo XIX, Fe en el hombre que desarrolla fuerzas incógnitas y se adueña del planeta: optimismo de los pensadores oficiales, paniaguados del orden moral y técnico. Otros pensadores discrepan de las consignas del poder; saben que la prosperidad general core pareja con la miseria creciente de la mayoría, pero estiman que una transformación armoniosa de la sociedad salvará todas las deficiencias, tampoco ponen en tela de juicio el futuro del hombre y de la técnica : optimismo de los pensadores socialistas que acusan el desorden tras el orden aparente y preparan alegre $\circ$ inconscientemente nuevas teorías, nuevas consignas, las nuevas tiranías del siglo $\mathrm{XX}$, un nuevo orden en el cual, menos que nunca, se permite no estar de acuerdo.

La discrepancia de Baudelaire, $e l l a$, es absoluta: las cosas no tienen arreglo y el poeta esperc las catástrofes que, tarde o temprano, han de despertar a los unos como a los otros. Después de "poner fecha" a su "cólera" o a su "tristeza", en el texto citado sobre el "fin del mundo", Baudelaire agregaba: "Por mí, que a veces siento la ridiculez de un profeta, sé que nunca alcanzaré la caridad de un médico"; desengañado del pasado, sin creer que las tormentas por venir traigan algo nuevo: "ni enseñanza, ni dolor", renuncia a todos los posibles remedios, remedios momentáneos, convencido de que el hombre "es siempre parecido, igual al hombre, es decir que está siempre en estado salvaje" .

Una sola vez el autor de Las Flores del Mal participó en sucesos políticos - participación sui generis, pues al recordarla explica: "Mi embriaguez en 1848. ¿De qué índole fué esa embriaguez? Amor a la venganza: Placer natural de la demolición; y juzgando en conjunto la revolución de febrero, apuntaría: "1848 sacó su encanto del exceso mismo de ridículo... cada cual edificaba utoías 
como castillos en el aire". "Placer natural de la demolición : "natural" está subrayado y no debemos olvidar la severidad de Baudelaire en general por lo que él llama naturaleza o nalural.

Desechados ciertos impulsos juveniles, en un capítulo del Corazón al desnudo, el poeta resumirá su posición "política" : "No tengo convicciones en el sentido de la gente de este siglo, porque no tengo ambición... Sólo los bandoleros están convencidos ¿De qué? de que tienen que lograr éxito. Y por eso les va bien en sus empresas... No obstante, añade Baudelaire, no obstante, tengo algunas convicciones, en un sentido más elevado, y que no puede entender la gente de mi tiempo" - convicciones absolutas que no se ajustan a las avenencias politiqueras, y que nadie perdona al poeta. El escándalo de la poesía no estriba en tal o cual verso crudo o licencioso de los "poemas condenados", sino en el hecho mismo de la poesía, cuando el poeta lo acepta plenamente y lo lleva a sus últimas consecuencias. Al requisitorio del representante del orden burgués, el Fiscal Pinard, en 1857, responde, o mejor dicho corresponde, 10 años más tarde, el año de la muerte de Baudelaire, el artículo de saña e insultos del escritor socialista. Jules Vallés, quien, entre otras cosas predecía: "Sus admiradores (de B.) pueden a lo más esperar para él que algún día un aficionado curioso o refinado disponga a ese loco en un volumen de cien ejemplares jüuntō con algunōs excéntricos cazcarrientos".

A raíz del proceso de Las Flores del Mal, Víctor Hugo, desterrado por "el régimene imperial, habiásescrito al poeta réprobo: "Lo que el régimen llama su justicia acaba de condenaros en nombre de lo que llama su moral". Sólo Hugo con su monstruosa ingenuidad, podía pensar que se trataba únicamente de una cuestión de régimen (1) y que bastaría cambiar el imperio por la república, la dictadura por la democracia, para reconciliar la poesía (no algunos poemas del propio Hugo) con la sociedad. Estemos seguros de que al leer la cartá del "glorioso mayor", Baudelaire no contuvo una sonrisa irónica; ¿en qué el paso de un régimen a otro - esos cambios que experimentamos cada día - iba a alterar la maledcción (la "benedicción") de su obra y de su vida.

(1) La multa impuesta por el tribunal fué reducida después de una intervención de la Emperatriz. 
Sus últimos gritos de protesta, en 1864-66, serán contra Bélgica ("la fe en el Progreso es una doctrina de Belgas"). Pero jcuántas veces anteriormente se había indignado en su propio país, de su propio país, no por culpa exclusiva de tal o cual gobierno: "Me aburro en Francia, sobre todo porque todos ahí se parecen a Voltaire... Voltaire, el anti-poeta,...", y en la carta a Ancelles sobre Las Flores del Mal : "Ud..ha sido lo suficiente niño como para olvidar que Francia le tiene horror a la poesía, a la verdadera poesía...".

Soledad de Baudelaire, lo advertimos al principio: en Francia, en Bélgica, en cualquier lugar o tiempo. ¿Será necesario precisar que no hablamos de una soledad inocente, hipócritamente inocente - soledad de la torre de marfil que recluye al solitario y lo separa del resto de la especie? "Ya hemos visto que Baudelaire sólo conoce la soledad que "compromete" y, en su caso, la imaginación tiene como corolario una sensibilidad excepcional, pronta a vibrar ante el ser más humilde - verdad que muchas veces se trata de un ser solitario al igual que el poeta: una anciana, un niño pobre, un saltimbangui decrépito - seres algunos que de los apóstoles panaceas sociales olvidan de considerar porque los estiman "irrecuperables".

Pero nosotros, que no tenemos panaceas, daremos crédito a tantas páginas del Esplín de París, donde aflora el orgullo de "vivir y sufrir en otros que símismo", o \& la advertennecia del Diario: "No despreciéts la sensibilidad de nadie. Ia sensibilidad de cada cual, es su genio'; y también recordaremos las palabras de Proust, definitivas: "El (Baudelaire) encuentra para todos los dolores, para todas las dulzuras, algunas de esas formas inauditas, arrebatadas a su propio mundo espiritual, y que nunca más se encontrarán en otro hombre... Pero, si bien habla con labios ruidosos como el trueno, se diría que procura hablar tan sólo con los labios, aunque uno siente que él lo ha experimentado todo, lo ha entendido, y que posee la sensibilidad más estremecida, la más profunda inteligencia".

De refilón, Proust nos indica una de las razones por las cuales, durante mucho tiempo se le ha negado a Baudelaire la sensibilidad, reteniendo únicamente su "perversidad", como si ambas no existieran juntas, la una por la otra. "Se diría que procura hablar tan sólo con los labios" : su aristocratismo nato y el pudor que opone al "débraillé", al libertinaje sentimental de un Musset o de 
la Sand, románticos de un romanticismo carente de estilo, sin nada que ver con el gran romanticismo de Chateaubriand y de "la escuela de la Melancolía" - todo ello hace que Baudelaire generalmente no confiese más que "con los labios su emoción; y por otro lado, conociendo la "perversidad" (2) que sólo le reprochan aquellos que se niegan a reconocerla en sí mismos, el poeta cersi siempre, como el filósofo de Descartes, aunque con distintos motivos, el poeta "avanza disfrazado" - lleva una, cuando no varias máscaras.

Tendríamos que haber hablado del dandismo. La cólera, la resolución de no plegarse a convenio alguno, llevan a expresar con sarcasmo y violencia la desconformidad absoluta con el mundo circundante - y la fé, cuando subsiste, en nada ayuda; al contrario: irrita la impaciencia, aumenta el deseo de la destrucción universal, que sola podría terminar con la vulgaridad universal. "Cuando haya inspirado el asco y el horror universales, tendré conqustada la soledad" : la soledad era un hecho, experimentado desde niño; es también un programa : a partir de una revelación primitiva indeclinable, llegar hasta el extremo, que casi nadie alcan$z a$, en que lo necesario se trueca en libertad - una libertad pavorosa, sellada por la muerte.

Durante mucho tiempo, el dandismo, o la voluntad de dandismo, habían marcado como una etapa - el dandismo que acogía todos los afanes de distinción. de espiritualismo y de sublime el dandismo nunca renegado, santidad de una especie extraordinaria, la única para la cual quien ante el espectáculo del mundo sentía la inquietud de los "profetas" sin el deseo de lucha de los "médicos" se hallaba dispuesto. La aparente insensibilidad de dandy es un arma de defensa estoica y su sola presencia constituye un escándalo, una provocación para los demás hombres.

El dandismo de Baudelaire : un dandismo ideal pues podemos dudar que el poeta haya alcanzado alguna vez la "altanería" absoluta de su modelo, pero si "la palabra dandy implica" asimismo "la quinta esencia del carácter y una inteligencia sutil de todo el mecanismo moral de este mundo", una actitud común al dandy y al poeta es el humor, el humor negro, un humorismo muy apartado del "ingenio" francés tradicional, dieciochesco, volteriano, como de la burla molieresca y de la sátira, un humorismo que aventaja al

(2) "La perversidad es su modo de conocimiento" (P. J. Jouve), al menos, uno de sus modos. 
sufrimiento mediante la negación feroz, cruel, acerba de cuanto se presenta bajo el aspecto del orden y la conformidad : a un honrado padre de familia que alababa las virtudes de sus dos hijas, el poeta preguntaba sin inmutarse : ¿Y cuál de las dos destina Ud. a la prostitución"; a.su propietario que se quejaba de cierta bulla nocturna contestaba: "No sé a que alude Ud. Parto leña en la sala; arrastro a mi amante de los cabellos, ¿quién no hace lo mismo?"; $y$ varios testigos se sorprendieron cuando, a ejemplo de Swift, elogió el sabor de los sesos de niño, manjar delicioso; hasta algunos llegaron a creer que verdaderamente él se alimentaba con platos tan fuera de uso.

El humor negro desconcierta a cuantos viven satisfechos con la vida tal o cual es, o tal como se imaginan que podría ser con la voluntad y las virtudes apropiadas; desconcierta porque desengaña : a Charles Monselet, literato vanidoso, que encontrándole un día en un "casino' de mala fáma, sentado en un rincón, y mirando al "desfile macabro" de los vividores y las bailarinas de cancán a Monselet que le decía: "¿Qué hace Ud. ahí?", Baudelaire se limitó a replicar : "Querido amigo, estoy viendo pasar a las calaveras".

El humor por fin cobra su sentido más profundo, trágico, desgarrador, cuando se sostiene hasta los últimos momentos y "sobrevive", tal vez inconsciente, al "naufragio" de las otras facultades : ya enfermo, afásico, cuando Cuna Camiga de lás bien intencionadas le presentó unjespejopparaiquel sé viera nos „ cuentan que el que fuera magnífico poeta miró el espejo, no se reconoció, y saludó.

Todo comentario resultaría sacrílego, indecente. En 1857, año de Las Flores del Mal, el comensal de los hermanos Goncourt: "sin corbata, con el cuello desnudo, la cabeza afeitada", como un reo de muerte, alguien preparado para la guillotina; en 1861, segunda edición de los poemas, el huésped de Catellu Mendés" : esbelto, elegante, un tanto furtivo, con la apariencia de un obispo delicado, algo réprobo, que se hubiese puesto, para viajar, vestidos exquisitos de seglar; su Eminencia Monseñor Brummel"; en 1867, la última imagen que acabamos de evocar : un "anciano precoz" que decide callar, y se lleva el secreto de sus visiones como de esas "convicciones" que no entendieron los coetáneos y que sólo el silencio, amén de paciencia y furor, podrán ayudarnos ahora a encontrar. 